\title{
HUBUNGAN KEBIASAAN MENGGOSOK GIGI DENGAN TIMBULNYA KARIES GIGI ANAK USIA SEKOLAH KELAS 4 SDN PUSPIPTEK TANGERANG SELATAN
}

\author{
Gita Ayuningtyas \\ Program Studi S1 Keperawatan, STIKes Widya Dharma Husada Tangerang \\ Jalan Pajajaran No1, Pamulang Tangerang Selatan Banten \\ gitaayuningtyas@wdh.ac.id
}

\begin{abstract}
ABSTRAK
Karies gigi merupakan salah satu masalah kesehatan yang banyak dialami oleh sebagian masyarakat indonesia. Penyakit ini merupakan masalah yang rentan dihadapi oleh anak usia sekolah. Tujuan: penelitian ini adalah untuk mengetahui hubungan kebiasaan menggosok gigi dengan timbulnya karies gigi anak usia sekolah kelas 4 SDN PUSPIPTEK Kota Tangerang Selatan. Penelitian ini bersifat kuantitatif. Metode penelitian: yang digunakan adalah desain analitik dengan pendekatan Cross Sectional, cara pengambilan data pada penelitian ini dengan cara kuesioner dan observasi. Hasil penelitian: kebiasaan menggosok gigi anak usia sekolah di SDN PUSPIPTEK Kota Tangerang Selatan dalam kategori buruk sebanyak 36 (49,3\%) responden dari 73 responden yang dijadikan sampel. Dan timbulnya karies gigi anak usia sekolah kelas 4 di SDN PUSPIPTEK Kota Tangerang Selatan dalam kategori yang mengalami karies gigi sebanyak 27 (37,0\%) responden dari 73 responden yang dijadikan sampel. Hasil analisis hubungan kebiasaan menggosok gigi dengan timbulnya karies gigi. Chi-square diperoleh nilai P-Value $=0,879$. Kesimpulannya: dari penelitian ini adalah tidak ada hubungan yang signifikan pada kebiasaan menggosok gigi dengan timbulnya karies gigi anak usia sekolah kelas 4 SDN PUSPIPTEK Kota Tangerang Selatan. Karies gigi yang dialami sebagian siswa/i mungkin lebih disebabkan karena pola makan mereka yang tidak baik, banyak makan makanan yang manis seperti: cokelat atau permen. Saran: diharapkan kepada siswa-siswi supaya rajin menggosok gigi minimal 2 kali sehari, terutama sehabis makan-makan yang manis.
\end{abstract}

Kata Kunci : Kebiasaan Menggosok Gigi, Timbulnya Karies Gigi

\section{ABSTRACT}

Dental caries is one of the many health problems experienced by some people of Indonesia. This disease is a problem susceptible to school-aged children. Maintenance of oral health is an attempt to prevent this disease. Purpose: This research is to know the correlation of tooth brushing habit with the incidence of dental caries of 4th graders of SDN PUSPIPTEK South Tangerang. This research is quantitative. Research method: used is an analytical design with Cross Sectional approach, how to collect data in this research by means of questionnaire and observation. Result of research: habit of brushing teeth of school age children in SDN PUSPIPTEK in bad category counted $36(49,3 \%)$ respondents from 73 respondents who made the sample. And the incidence of dental caries of 4th graders at SDN PUSPIPTEK in the category of dental caries as much as $27(37,0 \%)$ of respondents from 73 respondents who made the sample. Result of analysis of habitual relationship of brushing teeth with incidence of dental caries. Chi-square obtained value of P-Value $=0.879$. In conclusion: from this research there is no significant correlation to the habit of brushing teeth with the incidence of dental caries of 4th graders of SDN PUSPIPTEK South Tangerang. Dental caries experienced by some students may be due to their poor diet, eating lots of sweet foods such as chocolate or candy. Suggestion: expected to the students to be diligent to brush your teeth at least 2 times a day, especially after a sweet meal

Keywords: Dental Brushing, Incidence of Dental caries 


\section{PENDAHULUAN}

Saat ini masalah kesehatan gigi dan mulut cenderung mengalami peningkatan. Karies gigi merupakan salah satu masalah kesehatan yang banyak dialami oleh sebagian masyarakat di Indonesia. Penyakit ini merupakan masalah yang rentan dihadapi oleh anak usia sekolah dasar. Pemeliharaan kebersihan gigi dan mulut merupakan salah satu upaya meningkatkan kesehatan karena hal tersebut dapat mencegah terjadinya berbagai penyakit rongga mulut. Masalah kesehatan gigi dan mulut masyarakat Indonesia masih merupakan hal yang perlu mendapat perhatian serius dari tenaga kesehatan (WHO, 2012).

Menurut Riset Kesehatan Daerah (Riskesdas) tahun 2013 di provinsi Jawa barat menyatakan masalahkesehatan gigi dan mulut mengalami peningkatan dari tahun 2007 sebesar 25,3\% sampai tahun 2013 sebesar $28 \%$

Menurut Riset Kesehatan Daerah (Riskesdas) tahun 2013 di Kota Tangerang Selatan masalah kesehatan gigi dan mulut mengalami peningkatan dari tahun 2007 sebesar 19,9\% sampai 2013 sebesar $34,2 \%$ masalah kesehatan gigi dan mulut pada anak usia 10-14 tahun sebesar 20,6\% tahun 2007, dan mengalami peningkatan sebesar 25,2\% pada tahun 2013 .

Survey awal yang dilakukan peneliti tentang aktivitas mereka didapatkan bahwa dari beberapa siswa tersebut memiliki masalah pada gigi dan mulut. Hasilnya dari 6 orang terdapat 3 orang yang mengalami masalah pada gigi dan mulut mereka seperti bau mulut, gigi yang tanggal dan gigi yang berlubang. Hal ini disebabkan karena mereka sering makan makanan yang manis, tidak teratur dalam menggosok gigi dan belum melakukan sikat gigi dengan baik dan benar.

Dari uraian di atas peneliti tertarik untuk mengetahui "Hubungan Kebiasaan Menggosok Gigi Dengan Timbulnya Karies Gigi Anak Usia Sekolah Kelas 4 SDN PUSPIPTEK Kota Tangerang Selatan Tahun 2017”.

\section{METODE}

\section{Desain Penelitian}

Desain penelitian ini adalah penelitian 
deskriftif analitik dengan pendekatan Cross Sectional. Penelitian Cross Sectional adalah jenis penelitian yang menekankan waktu pengukuran atau observasi data variabel independen dan dependen hanya satu kali pada satu saat. (Nursalam, 2015).

\section{Lokasi dan Waktu Penelitian}

Lokasi penelitian di Sekolah Dasar Negeri PUSPIPTEK Kota Tangerang Selatan. Penelitian ini dilakukan pada bulan Februari Juni 2017.

\section{Populasi}

Populasi dalam penelitian ini adalah SiswaSiswi Kelas 4 SDN PUSPIPTEK Kota Tangerang Selatan.

Jumlah responden seluruhnya adalah 73 siswa/i.

\section{Sampel}

Teknik pengambilan sampel dalam penelitian ini adalah total sampling. Dan sampel yang didapatkan peneliti sebesar 73 orang.

\section{Analisa Data}

Analisis univariate pada penelitian ini untuk mengetahui distribusi frekuensi pada karakteristik responden (umur, jenis kelamin, kebiasaan menggosok gigi dan timbulnya karies gigi). Terdiri dari dua variabel yaitu hubungan kebiasaan menggosok gigi sebagai variabel independent dan timbulnya karies gigi sebagai variabel dependent.

Analisis bivariate dalam penelitian ini dilakukan untuk mengetahui hubungan kebiasaan menggosok gigi dengan timbulnya karies gigi menggunakan uji statistik Chi suare $\left(\mathrm{X}^{2}\right)$ dengan batas kemaknaan $\alpha=0,05 \%$ apabila nilai $\mathrm{P}<\alpha$ maka hasil perhitungan bermakna artinya ada hubungan kebiasaan menggosok gigi dengan timbulnya karies gigi anak usia sekolah kelas 4 SDN PUSPIPTEK Kota Tangerang Selatan. Dan apabila $\mathrm{P}>\alpha$ maka hasil perhitungan statistik bermakna artinya tidak ada hubungan kebiasaan menggosok gigi dengan timbulnya karies gigi anak usia sekolah kelas 4 SDN PUSPIPTEK Kota Tangerang Selatan. 


\section{HASIL PENELITIAN}

Analisa Univariat

Tabel 5.1 Karakteristik Responden Berdasarkan Usia $(n=73)$

\begin{tabular}{lccc}
\hline No & Usia & $\mathbf{N}$ & $\mathbf{\%}$ \\
\hline 1 & $<12$ tahun & 23 & 31,5 \\
\hline 2. & $>12$ tahun & 50 & 68,5 \\
& Total & 73 & 100 \\
& & &
\end{tabular}

Berdasarkan tabel 5.1 Distribusi frekuensi usia responden diperoleh lebih dari setengahnya responden $(68,5 \%)$ berusia $>12$ tahun, hampir setengahnya responden $(31,5 \%)$ berusia $>12$ tahun. Rata-rata usia terbanyak 11 tahun.

Tabel 5.2 Karakteristik Responden Berdasarkan Jenis Kelamin $(n=73)$

\begin{tabular}{cccc}
\hline No & Jenis & n & \% \\
& Kelamin & & \\
\hline 1. & Laki-laki & 41 & $56.2 \%$ \\
2. & Perempuan & 32 & $43.8 \%$ \\
& Total & 73 & $100 \%$ \\
\hline
\end{tabular}

\section{Berdasarkan tabel 5.2 Distribusi}

frekuensi responden berdasarkan jenis kelamin diperoleh lebih dari setengahnya responden $(56,2 \%)$ berjenis kelamin lakilaki dan hampir setengahnya responden $(43,8 \%)$ berjenis kelamin perempuan.

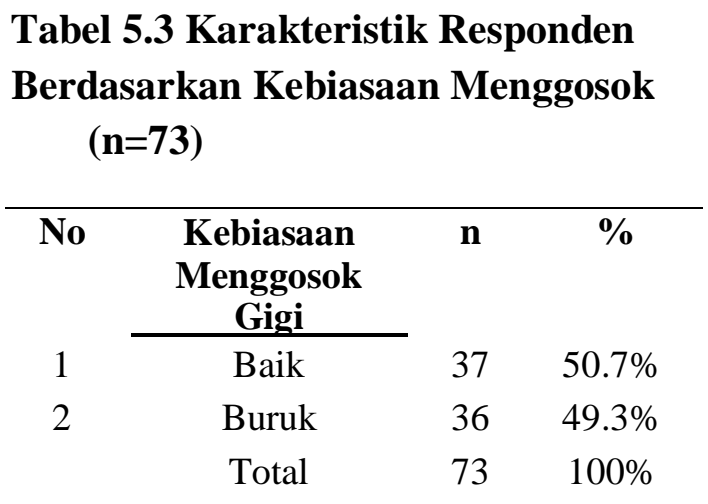

Berdasarkan tabel 5.3 Distribusi frekuensi responden berdasarkan kebiasaan menggosok gigi diperoleh setengahnya responden $(50,7 \%)$ memiliki kebiasaan menggosok gigi yang baik, dan hampir setengahnya responden $(49,3 \%)$ memiliki kebiasaan menggosok gigi yang buruk.

\section{Tabel 5.4 Karakteristik Responden \\ Berdasarkan Karies Gigi (n=73)}

\begin{tabular}{cccc}
\hline No & Karies Gigi & n & \% \\
\hline 1 & Tidak Ada & 46 & $63.0 \%$ \\
2 & Ada & 27 & $37.0 \%$ \\
& Total & 73 & $100 \%$
\end{tabular}

Berdasarkan tabel 5.4. Distribusi frekuensiberdasarka timbulnya karies gigi diperoleh lebih dari setengahnya responden (63\%) tidak ada karies gigi dan 37\% responden ada karies gigi. 


\section{ANALISA BIVARIAT}

\section{Tabel 5.5. Analisa Hubungan Kebiasaan Menggosok Gigi Dengan Timbulnya Karies Gigi $(\mathbf{n}=73)$}

\begin{tabular}{|c|c|c|c|c|c|c|c|}
\hline \multicolumn{8}{|c|}{ Analisa Bivariat } \\
\hline \multirow{3}{*}{ Siswa/i } & \multicolumn{4}{|c|}{ Karies Gigi } & \multirow[b]{2}{*}{ Total } & \multirow[b]{2}{*}{ OR $(95 \% \mathrm{CI})$} & \multirow[b]{2}{*}{ P-Value } \\
\hline & \multicolumn{2}{|c|}{$\begin{array}{c}\text { Tidak } \\
\text { Ada }\end{array}$} & \multicolumn{2}{|c|}{ Ada } & & & \\
\hline & $\mathrm{n}$ & $\%$ & $\underline{\mathrm{n}}$ & $\%$ & $\%$ & \multirow{4}{*}{$\begin{array}{c}0,929(0,359- \\
2,403)\end{array}$} & \multirow{4}{*}{0,879} \\
\hline KMG Baik & $\underline{23}$ & $\underline{31,50}$ & 14 & $\underline{19,20}$ & $37 \quad 50,70$ & & \\
\hline KMG Buruk & 23 & 31,50 & 13 & 17,80 & 3649,30 & & \\
\hline Total & 46 & 63 & 21 & 37 & 73100 & & \\
\hline
\end{tabular}

Berdasarkan tabel 5.5 Analisa hubungan kebiasaan menggosok gigi dengan timbulnya karies gigi diperoleh hampir setengahnya responden (31,50\%) mempunyai kebiasaan menggosok gigi baik dan tidak ada karies gigi, sebagian kecil responden $(19,20 \%)$ mempunyai kebiasaan menggosok gigi baik dan ada karies gigi, hampir setengahnya responden $(31,50 \%)$ mempunyai kebiasaan menggosok gigi buruk dan tidak ada karies gigi, dan sebagian kecil responden $(17,80 \%)$ mempunyai kebiasaan menggosok gigi buruk dan ada karies gigi.

Dari hasil uji statistik tersebut didapatkan nilai OR (Odds Ratio) = 0,929 yang berarti bahwa siswa/I yang memiliki kebiasaan menggosok gigi yang buruk memiliki peluang 1 kali untuk mengalami kejadian karies gigi dengan confidence interval (CI) yaitu $(95 \% \mathrm{CI}$ : 0,359-2,403) yang artinya 95\% diyakini bahwa rata-rata hubungan kebiasaan menggosok gigi dengan timbulnya karies gigi hasil terendah adalah 0,359 dan yang tertinggi adalah 2,403. Hasil uji statistik analisis kebiasaan menggosok gigi dengan timbulnya karies gigi diperoleh nilai $p$-value $=0,879<\mathrm{a}=0,05$ maka dapat disimpulkan bahwa Tidak Ada Hubungan Antara Kebiasaan Menggosok Gigi Dengan Timbulnya Karies Gigi Anak Usia Sekolah Kelas 4 SDN PUSPIPTEK Kota Tangerang Selatan. 


\section{PEMBAHASAN}

\section{Kebiasaan Menggosok Gigi}

Distribusi frekuensi responden berdasarkan kebiasaan menggosok gigi diperoleh setengahnya responden $(50,7 \%)$ memiliki kebiasaan menggosok gigi yang baik Sejalan dengan penelitian yang dilakukan oleh Widayati tahun 2014 tentang faktor yang berhubungan dengan karies gigi pada anak usia 4-6 tahun didapatkan sebagian kecil responden $(16,7 \%)$ responden memiliki kebiasaan menggosok gigi kurang baik dan sebagian besar responden $(83,3 \%)$ memiliki kebiasaan menggosok gigi baik.

\section{Karies Gigi}

Distribusi frekuensi timbulnya karies gigi didapatkan lebih dari setengahnya responden $(63 \%)$ tidak ada karies gigi.

Menurut Muttaqin tahun 2010 mengatakan bahwa karies gigi adalah sebuah infeksi yang merusak struktur gigi, penyakit ini menyebabkan gigi berlubang, jika tidak ditangani penyakit ini dapat menyebabkan nyeri, penanggalan gigi, infeksi, berbagai kasus barbahaya lainnya. Sejalan dengan penelitian yang dilakukan oleh Permatasari tahun 2014 didapatkan hampir seluruhnya responden (95\%) memiliki karies gigi dan hampir tidak ada responden $(5 \%)$ tidak memiliki karies gigi.

\section{Hubungan Kebiasaan Menggosok}

Gigi Dengan Timbulnya Karies Gigi

Dari hasil uji statistik tersebut didapatkan nilai OR (Odds Ratio) = 0,929 yang berarti bahwa siswa/I yang memiliki kebiasaan menggosok gigi yang buruk memiliki peluang 1 kali untuk mengalami kejadian karies gigi dengan confidence interval (CI) yaitu (95\% CI : 0,359-2,403) yang artinya 95\% diyakini bahwa rata-rata hubungan kebiasaan menggosok gigi dengan timbulnya karies gigi hasil terendah adalah 0,359 dan yang tertinggi adalah 2,403. Hasil uji statistik analisis kebiasaan menggosok gigi dengan timbulnya karies gigi diperoleh nilai $p$ value $=0,879<\mathrm{a}=0,05$ maka dapat disimpulkan bahwa ada Tidak Ada Hubungan Antara Kebiasaan Menggosok Gigi Dengan Timbulnya Karies Gigi Anak Usia Sekolah Kelas 4 SDN PUSPIPTEK Kota Tangerang Selatan 


\section{KESIMPULAN DAN SARAN}

\section{Kesimpulan}

Berdasarkan hasil penelitian ini maka dapat diambil kesimpulan sebagai berikut :

a. Teridentifikasi setengahnya responden $\quad(50,70 \%)$ memiliki kebiasaan menggosok gigi yang baik

b. Teridentifikasi lebih dari setengahnya responden (63\%) tidak memiliki karies gigi

c. Teridentifikasi hasil analisa hubungan kebiasaan menggosok gigi dengan timbulnya karies gigi didapatkan $p$ value $=0,879$ $>\alpha(0,05)$ yang artinya tidak ada hubungan yang signifikan antara kebiasaan menggosok gigi dengan timbulnya karies gigi.

\section{SARAN}

a. Bagi Instansi Pendidikan

Penelitian ini diharapkan dapat menjadi panduan bagi pengembangan ilmu di dunia keperawatan, khususnya mengenai pentingnya kesehatan gigi dan mulut pada anak usia sekolah. b. Bagi Sekolah SDN PUSPIPTEK Penelitian ini diharapkan dapat meningkatkan minat guru dalam upaya promosi kesehatan kepada siswa-siswi kelas 4 dalam rangka meningkatkan kesehatan dikhususnya kesehatan gigi dan mulut.

c. Bagi Peneliti Selanjutnya

Peneliti selanjutnya di sarankan untuk meneliti faktor lain yang menyebabkan karies gigi pada anak usia, penelitian denan metode berbeda dan dengan jumlah responden lebih banyak. sekolah.

\section{DAFTAR PUSTAKA}

Nursalam. 2015.Metodologi Penelitian Ilmu Keperawatan: Pendekatan Praktis. Salemba Medika : Jakarta

Permatasai, I. 2014. Hubungan Perilaku Menggosok Gigi Dan Pola Jajan Anak Dengan Kejadian Karies Gigi Pada Murid SD Negeri 157 Palembang. Palembang: Universitas Sriwijaya.

Riset Kesehatan Dasar tahun 2013

WHO tahun 2012

Widayati, N. 2015. Faktor Yang Berhubungan Dengan Karies Gigi Pada Anak Usia 4-6 Tahun. Surabaya: Universitas Airlangga. 